\title{
Secondary forest is utilized by Great Curassows (Crax rubra) and Great Tinamous (Tinamus major) in the absence of hunting
}

Author(s): Andrew Whitworth, Christopher Beirne, Eleanor Flatt, Ruthmery Pillco Huarcaya, Juan Carlos Cruz Diaz, Adrian Forsyth, Péter K. Molnár, and Juan S. Vargas Soto

Source: The Condor, 120(4):852-862.

Published By: American Ornithological Society

https://doi.org/10.1650/CONDOR-18-57.1

URL: http://www.bioone.org/doi/full/10.1650/CONDOR-18-57.1

BioOne (www.bioone.org) is a nonprofit, online aggregation of core research in the biological, ecological, and environmental sciences. BioOne provides a sustainable online platform for over 170 journals and books published by nonprofit societies, associations, museums, institutions, and presses.

Your use of this PDF, the BioOne Web site, and all posted and associated content indicates your acceptance of BioOne's Terms of Use, available at www.bioone.org/page/terms_of_use.

Usage of BioOne content is strictly limited to personal, educational, and non-commercial use. Commercial inquiries or rights and permissions requests should be directed to the individual publisher as copyright holder. 


\title{
Secondary forest is utilized by Great Curassows (Crax rubra) and Great Tinamous (Tinamus major) in the absence of hunting
}

\author{
Andrew Whitworth, ${ }^{1,2 *}$ Christopher Beirne, ${ }^{3}$ Eleanor Flatt, ${ }^{1}$ Ruthmery Pillco Huarcaya, ${ }^{1,4}$ Juan Carlos Cruz \\ Diaz, ${ }^{1,5}$ Adrian Forsyth, ${ }^{1,6}$ Péter K. Molnár, ${ }^{7,8}$ and Juan S. Vargas Soto ${ }^{7,8}$ \\ 1 Osa Conservation, Washington, D.C., USA \\ 2 Institute of Biodiversity, Animal Health and Comparative Medicine, College of Medical, Veterinary and Life Sciences, University of \\ Glasgow, Glasgow, Scotland, UK \\ ${ }^{3}$ Nicholas School of the Environment, Duke University, Durham, North Carolina, USA \\ ${ }^{4}$ Universidad Nacional San Antonio Abad del Cusco (UNSAAC), Peru \\ ${ }^{5}$ Instituto Internacional en Conservación y Manejo de Vida Silvestre, Universidad Nacional, Heredia, Costa Rica \\ ${ }^{6}$ Andes Amazon Fund, Washington, D.C., USA \\ 7 Department of Biological Sciences, University of Toronto Scarborough, Toronto, Ontario, Canada \\ ${ }^{8}$ Department of Ecology and Evolutionary Biology, University of Toronto, Toronto, Ontario, Canada \\ * Corresponding author: andy.w.whitworth@gmail.com
}

Submitted April 17, 2018; Accepted August 14, 2018; Published October 17, 2018

\begin{abstract}
Deforestation and hunting are the leading human-driven disturbances causing population declines of the vulnerable Great Curassow (Crax rubra) and the near threatened Great Tinamou (Tinamus major). These threats typically co-occur, with synergistic effects. We investigated habitat use of Great Curassows and Great Tinamous in the Matapalo corridor of the Osa Peninsula, southwest Costa Rica, where they are not hunted, to understand whether disturbed habitats can be suitable for these species. We analyzed camera trap data from 56 locations and 5579 trapping days using occupancy modeling. We obtained 195 independent captures of Great Curassows at 33 of 56 locations (59\%) and 429 independent captures of Great Tinamous at 37 of 56 locations (66\%). Great Curassow occupancy did not vary with habitat type but was negatively influenced by distance from roads and by elevation; detection probability varied with habitat type. Great Tinamou occupancy probability was principally related to habitat type; primary, secondary and plantation forest areas all displayed high occupancy probabilities, but occupancy of agricultural land was low. Our work suggests that secondary-growth forests can offer valuable complementary habitat to assist in the recovery of these declining species, at least when hunting is controlled and intact forests are nearby.
\end{abstract}

Keywords: conservation, Cracidae, detection probability, game birds, habitat disturbances, occupancy, secondary forest, Tinamidae

\section{Utilizacion de bosque secundario por el Crax rubra y el Tinamus major en ausencia de caza \\ RESUMEN}

La deforestación y la caza son los principales disturbios ocasionados por los seres humanos que están causando la disminución de las poblaciones amenazadas del Crax rubra 'vulnerable' y el Tinamous major 'casi amenazado'. Estas amenazas coinciden y sus efectos operan sinérgicamente. Investigamos el uso de hábitat por el C. rubra y el T. major, en el corredor Matapalo de la Osa Península, al suroeste de Costa Rica, donde estas especies no son cazadas, para entender si los hábitats perturbados pueden ser hábitats adecuados para estas dos especies. Mediante modelos de ocupación, analizamos los datos de captura de cámaras trampa, provenientes de 56 ubicaciones y 5579 trampas cámara-día. Obtuvimos 195 capturas independientes del C. rubra en 33 de 56 ubicaciones (59\%) y 429 capturas independientes de T. major en 37 de 56 ubicaciones (66\%). La ocupación del C. rubra no vario con el tipo de hábitat, pero fue negativamente influenciado por la distancia de la carretera y la elevación altitudinal, mientras que la probabilidad de detección vario con el tipo de hábitat. La probabilidad de ocupación del T. major estuvo principalmente relacionada con el tipo de hábitat; las áreas de bosque primario, secundario y plantaciones mostraron altas probabilidades de ocupación, mientras que la probabilidad de ocupación de las tierras agrícolas fue baja. Nuestro trabajo sugiere que los bosques de crecimiento secundario pueden ofrecer un hábitat complementario valioso para ayudar en la recuperación de estas especies en declive, al menos cuando la caza es controlada y cuando existan bosques intactos cercanos.

Palabras clave: aves de caza, bosque secundario, conservación, Cracidae, ocupación, perturbación del hábitat, probabilidad de detección, Tinamidae 


\section{INTRODUCTION}

Tropical game birds (Galliformes and Tinamidae) are vital links in the complex dynamics of Neotropical rainforest systems and provide key ecosystem services (Brooks et al. 2004, Sekercioglu 2006). They are a food base for apex and mid-level predators (mammals, reptiles, and birds), control invertebrate populations, and help shape their habitats by dispersing seeds (Whelan et al. 2008). In addition to fulfilling these ecological roles, rainforest game birds are also a traditional resource used by many indigenous cultures for social, economic, and cultural services (Strahl and Grajal 1991, Wenny et al. 2011). These include protein, materials to manufacture tools, religious significance, and, most recently, income from birdwatching and nature tourism (Redford 1992, Barros et al. 2011, Vas 2013).

Despite their importance, terrestrial game birds are a highly threatened group, with $>38 \%$ of species listed as near threatened or higher in the International Union for Conservation of Nature (IUCN) Red List (Keane et al. 2005, IUCN 2017). In Latin America, the most threatened family of Galliformes is the Cracidae (chachalacas, guans, curassows), in which $\sim 50 \%$ of species are listed as near threatened or higher, including several species that are close to extinction (Brooks and Fuller 2006). In the case of the tinamous, $29 \%$ of species are listed as near threatened or higher, and of these, $64 \%$ were recently upgraded to a higher level of threat category (IUCN 2017).

The principal threats game birds face are hunting and accelerating deforestation, habitat fragmentation, and habitat degradation (Bird et al. 2012, Radachowsky et al. 2012). Hunting of wild game has become the most widespread source of non-timber resource extraction in tropical rainforests (Peres 2001, Benítez-López et al. 2017). Deforestation and the introduction of roads can further exacerbate hunting pressure by simplifying access and allowing hunters to exploit once unreachable and undisturbed forests (Bonaudo et al. 2005). While regeneration of secondary forests may offset some of the negative consequences of the global decline in primary forest habitat (Chazdon et al. 2009), it is not yet clear to what degree such regeneration will benefit tropical game bird populations, especially considering the synergistic effects of hunting and habitat suitability on population persistence (Peres 2001, Wright 2003). Isolating the effects of habitat disturbance in the absence of hunting pressure is therefore critical for identifying the most effective management strategies for game species (Thomson et al. 2009, Thornton et al. 2012).

Here, we assess the habitat use of 2 important tropical game birds, the Great Curassow (Crax rubra) and the Great Tinamou (Tinamus major), in the Matapalo corridor of the Osa Peninsula, southwest Costa Rica. Globally, both species are under pressure due to hunting and loss of primary forest habitat (Brooks et al. 2004, Radachowsky et al. 2012). The Great Curassow is listed as vulnerable (BirdLife International 2018a), and the Great Tinamou is listed as near threatened on the IUCN Red List (BirdLife International 2018b).

Costa Rica is an ideal location in which to study the value of regenerating landscapes for these game birds. Primary forest cover was reduced from $67 \%$ to $17 \%$ of the original forest area between 1940 and 1987 (Sader and Joyce 1988, Hall et al. 2000). The Great Curassow had lost $69 \%$ of its original habitat by 1977 (Brooks 2006), and hunting was responsible for greatly reducing many populations to the point of local extirpation in some regions. Since then, favorable forestry laws and payment for ecosystem services, among other changes, have helped increase forest cover to $\sim 51 \%$. Of this, $24 \%$ is classified as primary forest, $9 \%$ as planted forests, and $67 \%$ as recovering secondary-growth forest (FAO 2010). No single primary forest patch in Costa Rica is adequate to support a genetically viable population of Great Curassows, so seconday forest is likely to be important for their persistence (Vaughan 2012).

We conducted a camera-trap survey across 4 habitat types (old-growth primary forest, naturally regenerating secondary forest, recovering secondary plantation forests, and active agricultural land) within a site that has been protected from hunting for $\geq 16 \mathrm{yr}$. In order to ensure that any effects detected were directly related to differences in habitat type, we investigated the potential influence of 4 other key covariates that could influence habitat use by tropical game birds: roads, rivers, elevation, and camera placement on or off trails. Rainforest roads are known to widely influence biodiversity patterns as a result of hunting access, edge effects, and changes in fruit distribution patterns (Martínez-Morales 1999, Whitworth et al. 2015, Gonçalves da Silva 2017, Nagy-Reis et al. 2017). Largebodied terrestrial birds have been found to associate with either riparian forest systems or terra firme interior forest (Martínez-Morales 1999, Haugaasen and Peres 2008). Elevation can be important for tinamou distributions (Estevo et al. 2017) and has been suggested as a driver of cracid populations (Kattan et al. 2016). Camera position on or off trail influences detection probability of rainforest vertebrates (Harmsen et al. 2010, Kays et al. 2010).

We hypothesized that in the absence of hunting, primary old-growth forest would display the highest levels of habitat use by game birds, with recovering secondary-growth forests used more frequently than active agricultural land.

\section{METHODS}

\section{Study Area and History}

The study was conducted in the Osa Peninsula, southwest Costa Rica, at Osa Verde Biological Station (formerly 


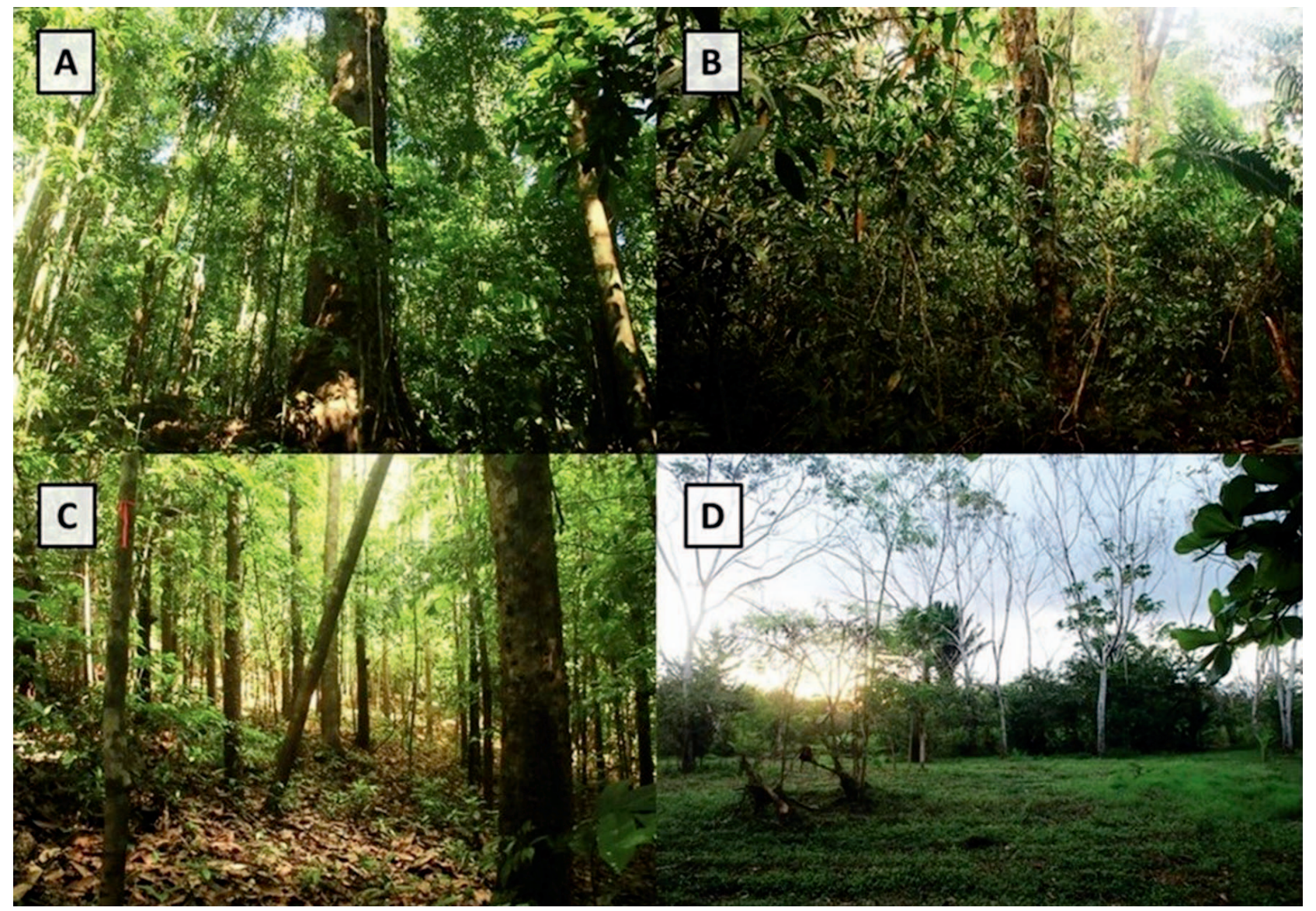

FIGURE 1. Representative photographs of the 4 major habitat types we investigated in the study site on the southeastern Pacific coastline of the Osa Peninsula, southwest Costa Rica: (A) old-growth primary forest containing giant mature Ajo trees (Caryocar costarincense); (B) naturally regenerating secondary-growth forest ( $40 \mathrm{yr}$ old); (C) secondary plantation forest (initially cattle pasture, followed by monoculture-style plantation, with recent enrichment planting); and (D) active agricultural farmland consisting of large open fields and fence lines of remnant forest strips.

known as Piro Biological Station; $\left.8.4038^{\circ} \mathrm{N}, 83.33661^{\circ} \mathrm{W}\right)$. Temperatures at the field site range between $23.3^{\circ} \mathrm{C}$ and $28.7^{\circ} \mathrm{C}$. Rainfall averages $3,584 \mathrm{~mm} \mathrm{yr}^{-1}$ and is seasonal, with a rainy season from June to November and a dry season from December to May.

Less than half of the original forested area in the Osa region is still covered by primary forest (Weissenhofer et al. 2001). Osa Verde Biological Station comprises 1,330 ha of privately protected land with a variety of habitat types, including old-growth primary forest, naturally regenerating secondary-growth forest, secondary plantation forest (cattle pastures that were converted to monoculture plantations $\sim 30$ yr ago, enriched by planting $>80,000$ trees of 50 native species over the past $3 \mathrm{yr}$ ), and active agricultural farmland matrix. The farmland contains standing fence lines of a variety of mature fruiting trees that provide shade for cattle (see Figure 1).

We combined 3 different sources of information for categorizing and mapping habitat types: local historical knowledge, a thesis detailing restoration in the secondary plantation forest (Foster 2002), and aerial imagery from Google Earth, the National Geographic Society archives in San Jose, and Sandor and Chazdon (2014).

The study area was previously owned by Fidencio Sanchez, whose father colonized the Osa Peninsula in 1924, and by his son Miguel Sanchez Urvina. Both Fidencio and Miguel provided firsthand knowledge of the land's history. From these interviews we know that large portions of the study area were completely cleared in the 1950s for rice, maize, and cattle grazing. Twenty years later, some of the land was abandoned and allowed to regenerate naturally. A small proportion was continually farmed and now hosts the Osa Verde organic farm, with neighboring connective remnant forest strips and areas of active reforestation.

Cerro Osa (the area that was previously a plantation and is now secondary growth) was completely cleared in 1970 for cattle grazing (Foster 2002). In 1988, monoculture 


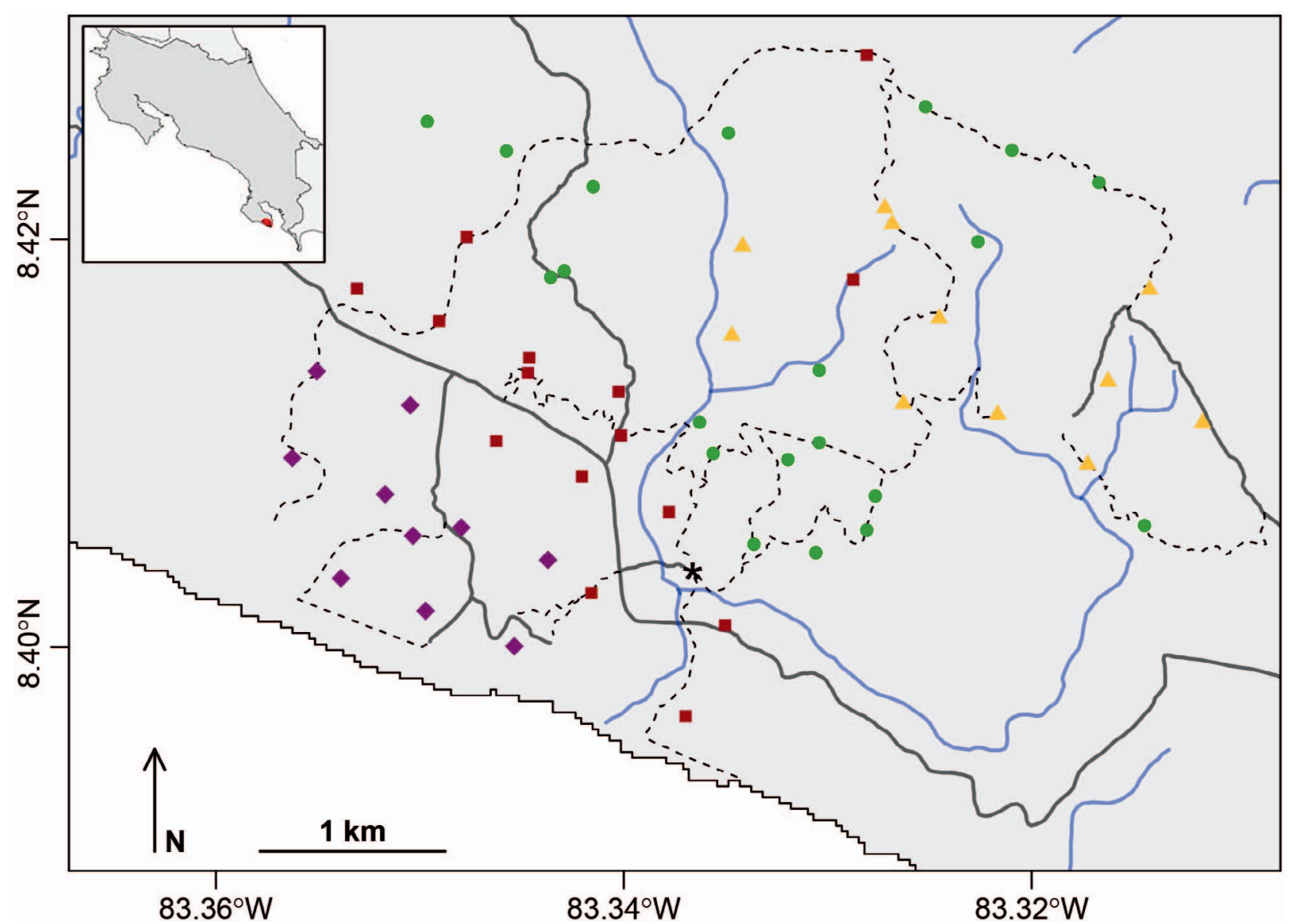

FIGURE 2. Survey design and map of the study location. Inset shows the location of the study site in southwest Costa Rica. Cameras were located in agricultural areas (purple diamonds), secondary-growth forest (red squares), old-growth forest (green circles), and old plantation forest (yellow triangles). Dashed lines represent small forest trails, solid gray lines represent gravel roads dissecting the forest, solid blue lines represent rivers, and the asterisk represents Osa Verde Biological Station.

stands of teak (Tectona grandis) and, shortly thereafter, pochote (Pachira quinata) were planted. In 1992, the land was purchased by the non-profit Osa Conservation, which enriched the monoculture plantations with native tree species in 2015-2017. In addition to this background information, we used aerial images to confirm site assignment.

\section{Data Collection}

Traditional transect techniques are generally unreliable for studying wildlife that exhibit a strong flight response to human observers (Thiollay 2005, Negret et al. 2015). Camera traps, by contrast, minimize researcher-bird contact and provide an effective means to study elusive ground-dwelling bird species (Winarni et al. 2005, O'Brien and Kinnaird 2008, Beirne et al. 2017, Whitworth and Williams 2017). We deployed 60 infrared camera traps (Bushnell Aggressor Red/Low Glow) across the study site from May to August 2017: 20 cameras located in primary forest, 18 in secondary forest, 11 in recovering plantation areas, and 11 within the agricultural matrix (see Figure 2). Forty-nine of these camera traps were deployed off trail following a $500 \times 500 \mathrm{~m}$ grid design, and an additional 11 camera traps were deployed on trail. No published information is available on Great Curassow home range size; Salvin's Curassow (Mitu salvini) has a 34 ha home range (Yumoto 1999). Great Tinamous at La Selva, Costa Rica, have a considerably smaller home range $(\sim 0.65$ ha for males and $\sim 3.2$ ha for females; Brennan 2012).

Two of the on-trail cameras adhered to the $500 \times 500 \mathrm{~m}$ grid design, while 9 cameras were embedded within the grid and, as such, were closer than the $500 \mathrm{~m}$ spacing of the other cameras. This design is not appropriate for calculating population density but is suitable for our goals of determining habitat use and preference or avoidance of trails (e.g., Harmsen et al. 2010, Kays et al. 2010). The camera traps were installed at about $20-30 \mathrm{~cm}$ height to ensure that Great Tinamous and Great Curassows did not 
TABLE 1. Top model set and corresponding $\beta$-coefficients for Great Curassows. Included are all models with $\triangle$ AIC $\leq 6$ from the bestsupported model, after excluding any models of which a simpler nested version attained stronger support. Each row represents a model in the top model set, and terms with $\beta$-estimates denote covariates included in the model.

\begin{tabular}{|c|c|c|c|c|c|c|c|c|c|c|c|}
\hline$\psi(\operatorname{lnt})$ & $p(\operatorname{lnt})$ & $\psi($ Habitat) & $\psi($ Road $)$ & $\psi($ Elevation) & $\psi$ (River) & $p$ (Habitat) & $p$ (Trail) & df & AIC & $\Delta \mathrm{AIC}$ & $w_{i}$ \\
\hline 0.53 & -1.73 & & -0.72 & & & $\checkmark$ & & 6 & 644.4 & 0.00 & 0.52 \\
\hline 0.47 & -1.74 & & & -0.58 & & $\checkmark$ & & 6 & 646.2 & 1.82 & 0.21 \\
\hline 0.45 & -1.37 & & -0.67 & & & & & 3 & 647.4 & 3.05 & 0.11 \\
\hline 0.48 & -1.70 & & & & & $\checkmark$ & & 5 & 647.8 & 3.48 & 0.09 \\
\hline 0.44 & -1.38 & & & -0.59 & & & & 3 & 648.3 & 3.93 & 0.07 \\
\hline 0.42 & -1.38 & & & & & & & 2 & 650.6 & 6.21 & 0.00 \\
\hline \multicolumn{2}{|c|}{ Cumulative weights } & 0.00 & 0.63 & 0.28 & 0.00 & 0.82 & 0.00 & & & & \\
\hline
\end{tabular}

Notes: $\psi=$ Occupancy probability; $p=$ detection probability; $\checkmark=$ categorical covariates with support; Int $=$ intercept; $\mathrm{df}=\mathrm{degrees}$ of freedom; $\mathrm{AIC}=$ Akaike's Information Criterion; $\triangle \mathrm{AIC}=$ deviation in AIC from the best-supported model; $w_{i}=$ Akaike model weight; and cumulative weights $=\Sigma w_{i}$ for each covariate (relative support).

escape detection (Thornton et al. 2012). Cameras were set to record $10 \mathrm{~s}$ videos with a minimum interval of $30 \mathrm{~s}$ between videos.

\section{Data Analysis}

To investigate correlates of habitat use by Great Curassows and Great Tinamous, we used an occupancy modeling framework, which accounts for imperfect detection through repeated surveys at multiple locations within a single season (MacKenzie et al. 2006). We estimated species-specific probabilities of detection ( $p$, the probability of detecting a species given that it is present) and occupancy ( $\Psi$, the probability of a site being occupied) using the single-season occupancy model in the UNMARKED package (Fiske and Chandler 2011) in the $R$ environment (R Core Team 2013). Detection histories were created by pooling detection data from every camera into 6 -day samples. Each sample was scored as " 1 " if there were one or more observations of a given species within the 6day interval, and " 0 " if the species was not recorded. Four camera traps were removed from the analysis (3 failed completely and 1 failed after 35 days of recording), resulting in a dataset involving 56 camera stations that were active for 10-19 six-day samples (median =18). We assessed the influence of 5 covariates hypothesized to influence game bird habitat use and ecology. For occupancy probability, these were (1) habitat type (primary, secondary, plantation, agricultural matrix), (2) distance to nearest river, (3) elevation, and (4) distance to nearest road. For detection probability we included (1) whether a camera was placed on or off a trail and (2) habitat type. Continuous covariates (distances and elevations) were scaled and standardized to have a mean of zero and unit variance.

Given that all covariates were weakly uncorrelated (Pearson's $r<0.5$ ), we tested all combinations of covariates, resulting in a suite of 64 candidate occupancy models. We applied an information-theoretic approach to model selection (Burnham and Anderson 2002) whereby candidate models were ranked using Akaike's Information Criterion (AIC). For each species, we defined a top model set that included all models with $\triangle \mathrm{AIC} \leq 6$ from the bestsupported model, after excluding any models of which a simpler nested version attained stronger support (following the "nesting rule" of Richards et al. 2011). This approach avoided selecting and interpreting spurious covariates (see Galipaud et al. 2017). We identified informative covariates based on their relative support, defined here as the sum of Akaike weights across all the top models in which the covariate occurs, and on their absolute importance, defined here as the magnitude of each covariate's effect on occupancy or detection probability estimates.

\section{RESULTS}

Our survey totaled 5,579 trap nights between May and August 2017. We obtained 195 independent captures (117 males and 78 females; with 15 instances of male and female together) of Great Curassows from 33 of 56 locations $(59 \%)$. For Great Tinamous, we had 429 independent captures at 37 of 56 locations $(66 \%)$.

\section{Great Curassow}

Among the factors hypothesized to influence Great Curassow occupancy probability, a negative effect of distance from roads received the strongest relative support, and a negative effect of elevation had weaker support (Table 1). Predicted occupancy was reduced by $71 \%$ across the road distance gradient (Figure $3 \mathrm{~A}$ ) and by $54 \%$ across the elevation gradient (Figure 3B). The predicted occupancy at mean distance from the road and mean elevation was 0.63 (95\% confidence interval [CI]: 0.48-0.76). There was no support for habitat type or 

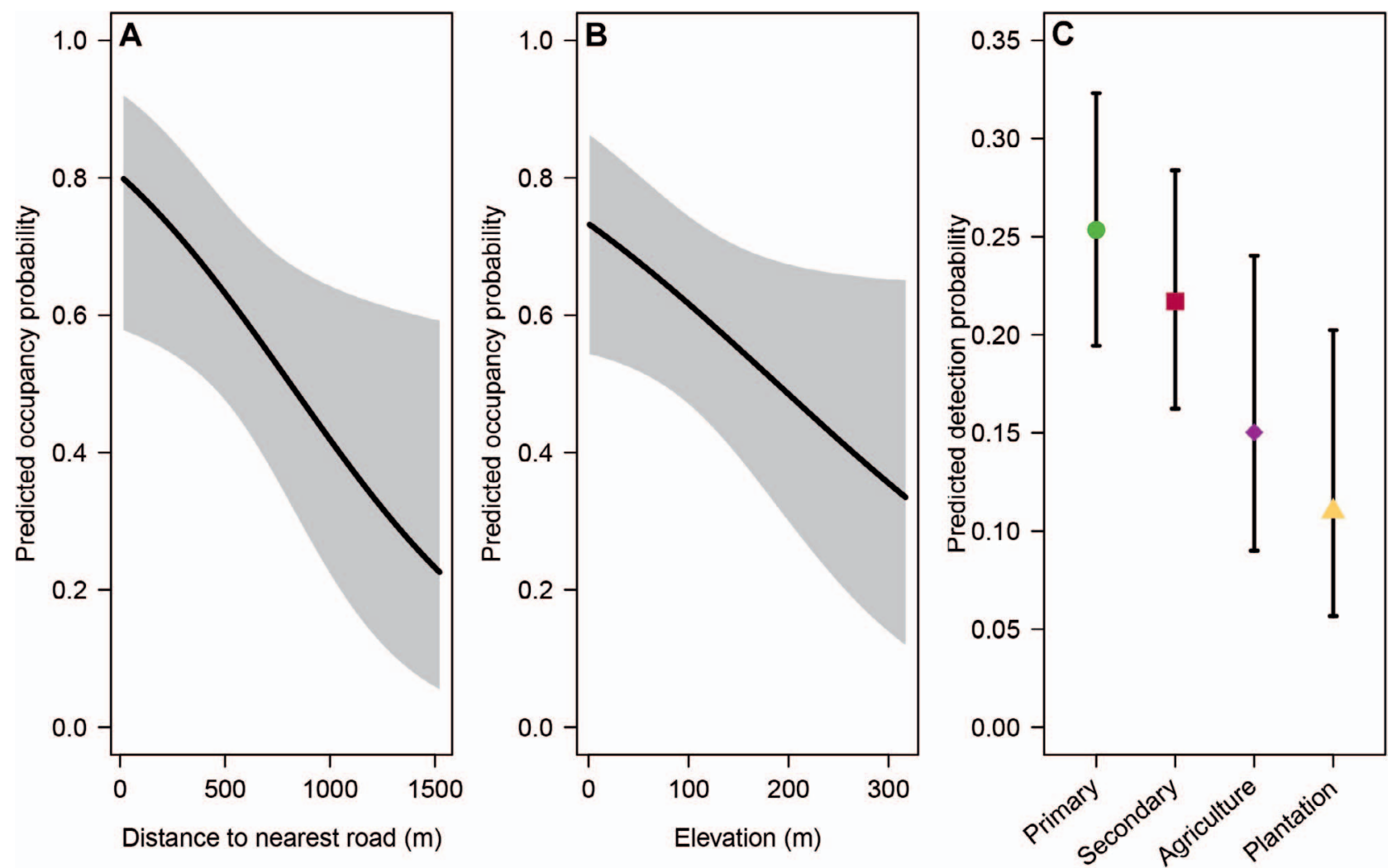

FIGURE 3. Negative effects of (A) distance to nearest road and (B) elevation on predicted occupancy by Great Curassows and (C) effect of habitat type on Great Curassow detection probability in the study site in southwest Costa Rica. Shaded areas in $\mathbf{A}$ and $\mathbf{B}$ and lines in C represent $95 \%$ confidence intervals. Plots based on the top candidate model in which each respective covariate is present.

distance to river in influencing occupancy probability. There was support for habitat type influencing Great Curassow detection probability, although CIs overlapped widely (Figure 3C; primary forest mean $=0.25,95 \% \mathrm{CI}$ : $0.19-0.32$; secondary forest mean $=0.22,95 \%$ CI: $0.16-$ 0.28 ; plantation forest mean $=0.11,95 \%$ CI: $0.06-0.20$; agricultural matrix mean $=0.15,95 \%$ CI: $0.09-0.24$ ). There was no support for the position of cameras on or off trails influencing detection probability.

\section{Great Tinamou}

The strongest predictor of Great Tinamou occupancy probability was habitat type: primary, secondary, and plantation forest areas all displayed similar occupancy probabilities, whereas agricultural land had lower occupancy (Table 2 and Figure 4A; predicted occupancy at mean river distance and elevation: primary forest mean $=$ 0.85, 95\% CI: $0.60-0.96$; secondary forest mean $=0.87$, $95 \%$ CI: 0.51-0.98; plantation forest mean $=0.86,95 \% \mathrm{CI}$ : $0.41-0.98$; agricultural matrix mean $=0.06,95 \%$ CI: 0.004-0.47). There was weaker support for a negative relationship between occupancy and elevation and for a positive relationship with distance from rivers (Table 2).
Predicted occupancy increased by $71 \%$ across the river distance gradient (Figure $4 \mathrm{~B}$ ) and decreased by $43 \%$ across the elevation gradient (Figure 4C). There was no support for effects of road distance on occupancy or of habitat type on detection probability (mean detection probability $=0.3$, 95\% CI: 0.26-0.34). There was no support for the position of cameras on or off trails influencing detection probability.

\section{DISCUSSION}

Previous studies have suggested that Great Tinamous prefer dense primary forests and infrequently utilize secondary-growth forest (Brooks et al. 2004, Schelsky 2004). Likewise, Great Curassows have previously been found to prefer undisturbed humid forests and to be tolerant of only minor disturbances (Radachowsky et al. 2012, BirdLife International 2018a) and, as such, have been considered a bioindicator of forest health (Brooks and Fuller 2006). Both species have been listed as old-growth forest specialists in the Yucatán Peninsula of Mexico (Urquiza-Haas et al. 2009). We found that both species were able to use secondary-growth forest, albeit to varying 
TABLE 2. Top model set and corresponding $\beta$-coefficients for Great Tinamous. Included are all models with $\Delta$ AIC $\leq 6$ from the bestsupported model, after excluding any models of which a simpler nested version attained stronger support. Each row represents a model in the top model set, and terms with $\beta$-estimates denote covariates included in the model.

\begin{tabular}{|c|c|c|c|c|c|c|c|c|c|c|c|}
\hline$\psi(\operatorname{lnt})$ & $p(\operatorname{lnt})$ & $\psi($ Habitat) & $\psi($ Road $)$ & $\psi$ (Elevation) & $\psi$ (River) & $p$ (Habitat) & $p$ (Trail) & $\mathrm{df}$ & $\mathrm{AIC}$ & $\Delta \mathrm{AIC}$ & $w_{i}$ \\
\hline-2.82 & -0.85 & $\checkmark$ & & -0.83 & 1.18 & & & 7 & 838.1 & 0.00 & 0.44 \\
\hline-1.81 & -0.85 & $\checkmark$ & & & 0.98 & & & 6 & 839.5 & 1.38 & 0.22 \\
\hline-0.97 & -0.85 & $\checkmark$ & & -0.67 & & & & 6 & 840.2 & 2.08 & 0.16 \\
\hline-0.40 & -0.85 & $\checkmark$ & & & & & & 5 & 840.7 & 2.64 & 0.12 \\
\hline 0.70 & -0.85 & & & -0.44 & & & & 3 & 843.3 & 5.18 & 0.03 \\
\hline 0.68 & -0.85 & & & & & & & 2 & 843.7 & 5.63 & 0.03 \\
\hline \multicolumn{2}{|c|}{ Cumulative weights } & 0.94 & 0.00 & 0.63 & 0.67 & 0.00 & 0.00 & & & & \\
\hline
\end{tabular}

Notes: $\psi=$ Occupancy probability; $p=$ detection probability; $\checkmark=$ categorical covariates with support; Int $=\mathrm{intercept}$; df $=\mathrm{degrees}$ of freedom; $\mathrm{AIC}=$ Akaike's Information Criterion; $\triangle \mathrm{AIC}=$ deviation in AIC from the best-supported model; $w_{i}=$ Akaike model weight; and cumulative weights $=\Sigma w_{i}$ for each covariate (relative support).

degrees. The use of secondary growth at this site is likely due to the synergistic effects of 3 major factors. First, hunting has been eradicated in the area since the establishment of the reserve by Osa Conservation in 2002. Second, remaining tracts of old-growth forest likely allowed recolonization into recovering habitats (Baker et al. 2015, Michalski and Peres 2017). Third, secondary and plantation forests $>40 \mathrm{yr}$ old are developed enough to be used by primary forest species (Chazdon et al. 2009, Powell et al. 2013).

Our finding that Great Curassow occupancy probability was higher closer to roads may seem surprising, especially considering that roads play a role in opening up tropical forests to destructive forces such as hunting (Forman and Alexander 1998). However, road clearings can also raise fruit production rates (Gonçalves da Silva 2017), and the
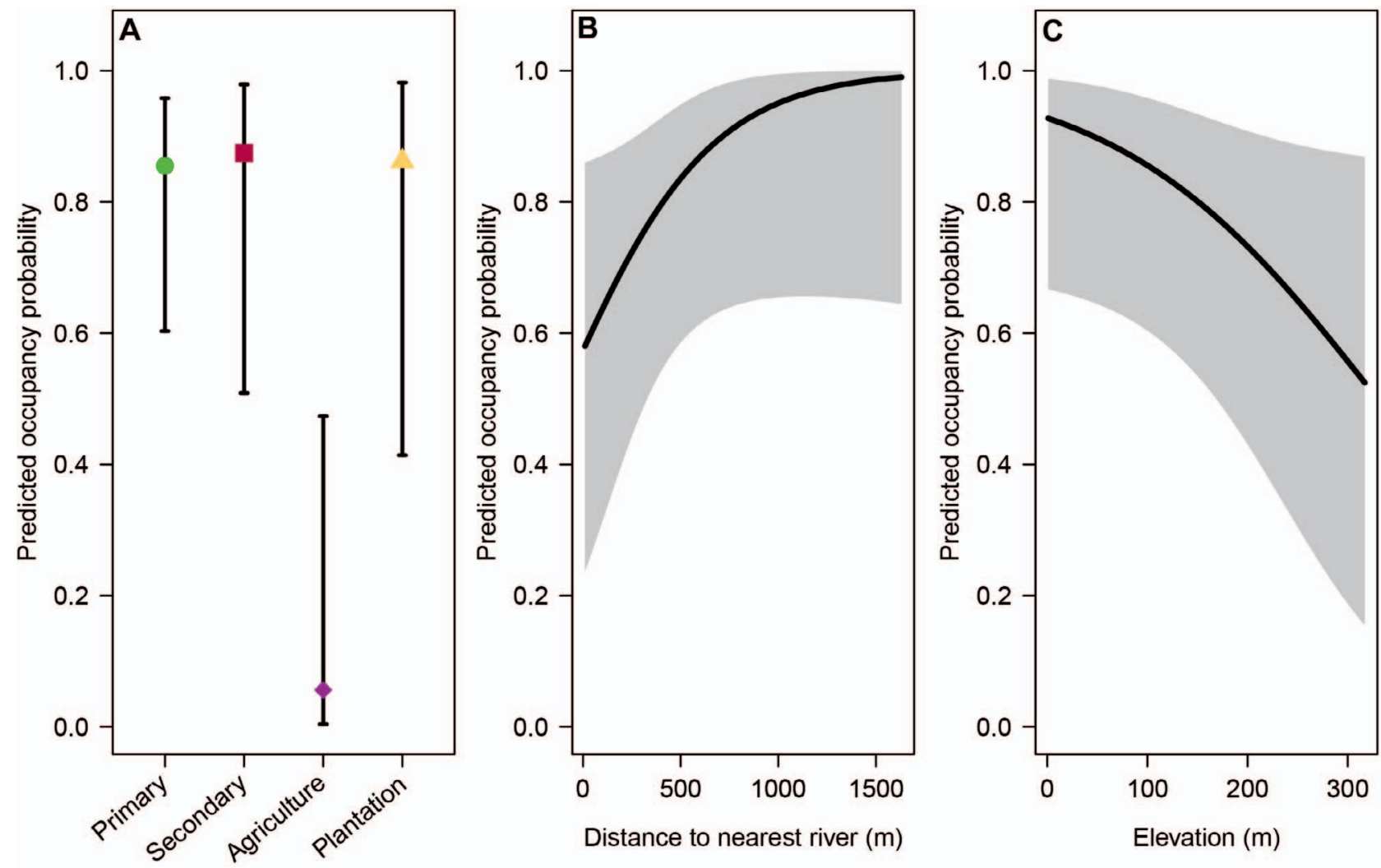

FIGURE 4. (A) Difference in Great Tinamou occupancy between habitats. (B) Positive effect of distance to river and (C) negative effect of elevation on Great Tinamou occupancy in the study site in southwest Costa Rica. Shaded areas in B and C and lines in $\mathbf{A}$ represent $95 \%$ confidence intervals. Plots are based on the top candidate model. 
resulting increase in fruit availability close to road edges can be attractive to frugivores such as Great Curassows (especially when hunting is controlled and the danger of direct collisions with vehicles is limited, as in our study area). If hunting were to return to the study area, Great Curassows would be under considerable threat, as roads provide hunters easy access to these naive birds (Constantino 2016, Benítez-López et al. 2017), also making hunters less likely to venture deeper into the forest for smaller game such as Great Tinamous (Kattan et al. 2016). Essentially, non-primary forests alongside roads have the potential to act as "ecological traps" for Great Curassows (Coffin 2007), attracting them to favorable habitat for food where they are more likely to be shot.

Habitat type was the strongest predictor of Great Tinamou occupancy probability. The Great Tinamou appears to be a forest-obligate species, rarely using the agricultural matrix but occupying all forested habitat types equally. It is probable that the clearings within this agricultural matrix act as barriers (Schelsky 2004), and the remnant forest strips offer no suitable refuge for this forest-loving species. All other habitats provided contiguous forest cover and, thus, valuable protection for ground nests (Blandón et al. 2016). Increased habitat use farther from rivers could be caused by the avoidance of edge habitats and a preference for dry, closed-canopy forest (Kuhnen et al. 2013). The weak support for lower occupancy at higher elevations that we detected here for Great Tinamous has been documented as a significant factor on occupancy for Tataupa Tinamous (Crypturellus tataupa) in Brazil, albeit over a greater elevational range (Estevo et al. 2017).

Although predicted occupancy was similar across habitats for Great Curassows, habitat type was a strong predictor of detection probability. This could relate to more regular use of old growth and naturally regenerating forests compared with active agricultural land, despite occupancy of all habitats. Alternatively, detection probability could be affected by differences in behavior or habitat structure. We consider the latter less likely, given that all habitats (with the exception of the agricultural matrix) had cameras located in closed-canopy forest, and all camera locations were standardized to minimize structural differences by clearing a 5-m-radius area in front of each camera and placing cameras at a standardized height. Cameras on agricultural land were located in the forest strips where forest cover was present. We cannot rule out possible behavioral changes induced by habitat type (i.e. Great Curassows spending more time on the ground in a given habitat), but nothing was obviously visible in the video footage. As such, we believe that the difference in detectability among habitat types is likely a result of differences in frequency of habitat use. The preference to spend a greater amount of time in the agricultural matrix than in former plantation areas could be due to the standing fence lines of mature fruiting trees that were never cleared from the agricultural matrix (Gilroy et al. 2015). By contrast, the plantation areas were completely cleared, eradicating fruit resources for Great Curassows (Sandor and Chazdon 2014) and altering the structural characteristics of the forest in ways that reduce the availability of suitable arboreal nesting sites (Daily et al. 2001).

The male-biased capture ratio of Great Curassows in our study supports the success of programs to eliminate hunting at Osa Verde. Given their striking bill coloration and easy detection during mating displays, males are more easily detected and killed by hunters (Pardo et al. 2017). Consequently, where hunting is present, sex ratios are typically skewed toward females (Martínez-Morales et al. 2009, Pardo et al. 2017). Absence of hunting may also release mesopredators (e.g., coatis, capuchins, and racoons) that prey on nesting females. Continued persistence of game birds, especially prized species such as the Great Curassow, will require ongoing control of hunting.

Our 4-month study, covering the transition from dry to wet season in a single year, does not reveal habitat use during other times of the year or inter-annual trends. Long-term monitoring of multiple secondary forests of a variety of ages would be valuable to establish thresholds for when recovering secondary forests become useful to game bird species. One recent study from La Selva Biological Station in Costa Rica assessed ongoing avifaunal change accompanying forest recovery and protection from hunting over 23 yr (Boyle and Sigel 2015). The Great Curassow and Great Tinamou were both among the $31 \%$ of species found to have increased in detections over that period. To the extent that our occupancy results reveal successful population-level recovery of these 2 species within abandoned agricultural landscapes, colonization from source populations in nearby primary forest and Corcovado National Park (15 km to the west) has probably been important. In the absence of natural colonization, our results suggest that landscapes like Osa Verde would be suitable for reintroduction of game birds if they could be protected from hunting.

\section{ACKNOWLEDGMENTS}

We are thankful for the support of all staff and volunteers of Osa Conservation. Thanks to the Bobolink Foundation and to the International Conservation Fund of Canada for their support of conservation in the Osa. Thanks to both the Instituto Internacional en Conservación y Manejo de Vida Silvestre, Universidad Nacional de Costa Rica, and to L. and J. Regan, who provided additional camera traps for the project. Thanks to R. Buchholz and three anonymous reviewers who 
provided comments and edits that improved the quality of the manuscript.

Funding statement: P.K.M. is grateful for support from an NSERC (Natural Sciences and Engineering Research Council of Canada) Discovery Grant, CFI (Canada Foundation for Innovation) John R. Evans Leader Funds, MRIS Ontario Research Funds, and University of Toronto Scarborough Research Competitiveness Funds.

Ethics statement: Appropriate permissions were obtained for the work, and the work raises no ethical issues.

Author contributions: A.W., J.S.V.S., R.P.H., E.F., and P.K.M. conceived the study. A.W., J.S.V.S.. E.F., and R.P.H. designed the methods. A.W., E.F., R.P.H., and J.S.V.S. conducted the research and collected the data. A.W. and C.B. analyzed the data. A.W., C.B., E.F., P.K.M., J.S.V.S., and A.F. wrote the paper. A.W., J.C.C.D., P.K.M., and A.F. contributed substantial resources.

Data deposits: Data are available at the University of Glasgow's data repository, Enlighten (http://dx.doi.org/10. 5525/gla.researchdata.643).

\section{LITERATURE CITED}

Baker, S. C., C. B. Halpern, T. J. Wardlaw, R. L. Crawford, R. E. Bigley, G. J. Edgar, S. A. Evans, J. F. Franklin, G. J. Jordan, Y. Karpievitch, T. A. Spies, and R. J. Thomson (2015). Short- and long-term benefits for forest biodiversity of retaining unlogged patches in harvested areas. Forest Ecology and Management 353:187-195.

Barros, F. B., H. M. Pereira, and L. Vicente (2011). Use and knowledge of the Razor-billed Curassow by a riverine community of the Oriental Amazonia, Brazil. Journal of Ethnobiology and Ethnomedicine 7(1).

Beirne, C., R. Pillco-Huarcaya, S. J. Serrano-Rojas, and A. Whitworth (2017). Terrestrial camera traps: Essential tool for the detection and future monitoring of the critically endangered Sira Curassow Pauxi koepckeae. Endangered Species Research 32:145-152.

Benítez-López, A., R. Alkemade, A. M. Schipper, D. J. Ingram, P. A. Verweij, J. A. J. Eikelboom, and M. A. J. Huijbregts (2017). The impact of hunting on tropical mammal and bird populations. Science 356:180-183.

Bird, J. P., G. M. Buchanan, A. C. Lees, R. P. Clay, P. F. Develey, I. Yépez, and S. H. M. Butchart (2012). Integrating spatially explicit habitat projections into extinction risk assessments: A reassessment of Amazonian avifauna incorporating projected deforestation. Diversity and Distributions 18:273-281.

BirdLife International (2018a) Species factsheet: Crax rubra. http://datazone.birdlife.org/species/factsheet/22678521

BirdLife International (2018b) Species factsheet: Tinamus major. http://datazone.birdlife.org/species/factsheet/Great-Tinamou

Blandón, A. C., S. B. Perelman, M. Ramírez, A. López, O. Javier, and C. S. Robbins (2016). Temporal bird community dynamics are strongly affected by landscape fragmentation in a Central American tropical forest region. Biodiversity and Conservation 25:311-330.

Bonaudo, T., Y. Le Pendu, J. F. Faure, and D. Quanz (2005). The effects of deforestation on wildlife along the transamazon highway. European Journal of Wildlife Research 51:199-206.
Boyle, W. A., and B. J. Sigel (2015). Ongoing changes in the avifauna of La Selva Biological Station, Costa Rica: Twentythree years of Christmas Bird Counts. Biological Conservation 188:11-21.

Brennan, P. L. R. (2012). Mixed paternity despite high male parental care in Great Tinamous and other Palaeognathes. Animal Behaviour 84:693-699.

Brooks, D. M. (Editor) (2006). Conserving Cracids: The Most Threatened Family of Birds in the Americas. Miscellaneous Publications of the Houston Museum of Natural Science 6.

Brooks, D. M., and R. A. Fuller (2006). Biology and conservation of cracids. In Conserving Cracids: The Most Threatened Family of Birds in the Americas (D. M. Brooks, Editor). Miscellaneous Publications of the Houston Museum of Natural Science 6. pp. 10-22.

Brooks, D. M., L. Pando-Vasquez, A. Ocmin-Petit, and J. TejadaRenjifo (2004). Resource separation in a Napo-Amazonian tinamou community. Ornitología Neotropical 15:323-328.

Burnham, K., and D. R. Anderson (2002). Model Selection and Multimodel Inference: A Practical Information-Theoretic Approach, second edition. Springer, New York, NY, USA.

Chazdon, R. L., C. A. Peres, D. Dent, D. Sheil, A. E. Lugo, D. Lamb, N. E. Stork, and S. E. Miller (2009). The potential for species conservation in tropical secondary forests. Conservation Biology 23:1406-1417.

Coffin, A. W. (2007). From roadkill to road ecology: A review of the ecological effects of roads. Journal of Transport Geography 15:396-406.

Constantino, P. A. L. (2016). Deforestation and hunting effects on wildlife across Amazonian indigenous lands. Ecology and Society 21(2):3.

Daily, G. C., P. R. Ehrlich, and G. A. Sánchez-Azofeifa (2001). Countryside biogeography: Use of human-dominated habitats by the avifauna of southern Costa Rica. Ecological Applications 11:1-13.

Estevo, C. A., M. B. Nagy-Reis, and J. D. Nichols (2017). When habitat matters: Habitat preferences can modulate cooccurrence patterns of similar sympatric species. PLOS One 12:e0179489.

FAO (Food and Agriculture Organization of the United Nations) (2010). Global forest resources assessment. Main report, FAO Forest paper 163. Data summary. https://rainforests. mongabay.com/deforestation/2000/Costa_Rica.htm

Fiske, I., and R. Chandler (2011). unmarked: An R package for fitting hierarchical models of wildlife occurrence and abundance. Journal of Statistical Software 43(10).

Forman, R. T. T., and L. E. Alexander (1998). Roads and their major ecological effects. Annual Review of Ecology and Systematics 29:207-231.

Foster, A. G. (2002) Cerro Osa: A ten year case study in tropical rainforest conservation management from the Osa Peninsula, Costa Rica. M.S. thesis, University of Washington, Seattle, WA, USA.

Galipaud, M., M. A. F. Gillingham, and F.-X. DechaumeMoncharmont (2017). A farewell to the sum of Akaike weights: The benefits of alternative metrics for variable importance estimations in model selection. Methods in Ecology and Evolution 8:1668-1678.

Gilroy, J. J., G. W. Prescott, J. S. Cardenas, P. G. D. P. Castañeda, A. Sánchez, L. E. Rojas-Murcia, C. A. Medina Uribe, T. Haugaasen, and D. P. Edwards (2015). Minimizing the biodiversity impact 
of Neotropical oil palm development. Global Change Biology 21:1531-1540.

Gonçalves da Silva, B. (2017). Effects of roads and trails on vegetation, fruit availability and birds in a protected area of Altantic Forest in southeastern Brazil. Universidade Estadual de Campinas, Instituto de Biologia:1-187.

Hall, C. A. S., M. Hall, and B. Aquilar (2000). A brief historical and visual introduction to Costa Rica. In Quantifying Sustainable Development: The Future of Tropical Economies (C. A. S. Hall, Editor). Academic Press, San Diego, CA, USA. pp. 19-42.

Harmsen, B. J., R. J. Foster, S. Silver, L. Ostro, and C. P. Doncaster (2010). Differential use of trails by forest mammals and the implications for camera-trap studies: A case study from Belize. Biotropica 42:126-133.

Haugaasen, T., and C. A. Peres (2008). Population abundance and biomass of large-bodied birds in Amazonian flooded and unflooded forests. Bird Conservation International 18:87-101.

IUCN (2017). The IUCN Red List of Threatened Species. Version 2017-3. The IUCN Red List of Threatened Species 2017. http:// www.iucnredlist.org

Kattan, G. H., M. C. Muñoz, and D. W. Kikuchi (2016). Population densities of curassows, guans, and chachalacas (Cracidae): Effects of body size, habitat, season, and hunting. The Condor 118:24-32.

Kays, R., S. Tilak, B. Kranstauber, P. A. Jansen, C. Carbone, M. J. Rowcliffe, T. Fountain, J. Eggert, and Z. He (2010). Monitoring wild animal communities with arrays of motion sensitive camera traps. arXiv:1009.5718.

Keane, A., M. D. L. Brooke, and P. J. K. McGowan (2005). Correlates of extinction risk and hunting pressure in gamebirds (Galliformes). Biological Conservation 126:216-233.

Kuhnen, V. V., R. E. M. De Lima, J. F. Santos, and L. C. P. Machado FilhoMachado FilhoL. C. P. (2013). Habitat use and circadian pattern of Solitary Tinamou Tinamus solitarius in a southern Brazilian Atlantic rainforest. Bird Conservation International 23:78-82.

MacKenzie, D. I., J. D. Nichols, J. A. Royle, K. H. Pollock, J. E. Hines, and L. L. Bailey (2006). Occupancy Estimation and Modeling: Inferring Patterns and Dynamics of Species Occurrence. Elsevier, Amsterdam, The Netherlands.

Martínez-Morales, M. A. (1999). Conservation status and habitat preferences of the Cozumel Curassow. The Condor 101:1420.

Martínez-Morales, M. A., P. C. Cruz, and A. D. Cuarón (2009). Predicted population trends for Cozumel Curassows (Crax rubra griscomi): Empirical evidence and predictive models in the face of climate change. Journal of Field Ornithology 80: 317-327.

Michalski, F., and C. A. Peres (2017). Gamebird responses to anthropogenic forest fragmentation and degradation in a southern Amazonian landscape. PeerJ 5:e3442.

Nagy-Reis, M. B., J. D. Nichols, A. G. Chiarello, M. C. Ribeiro, and E. Z. F. Setz (2017). Landscape use and co-occurrence patterns of Neotropical spotted cats. PLOS One 12:e0168441.

Negret, P. J., O. Garzón, P. R. Stevenson, and O. Laverde-R. (2015). New ecological information for the Black Tinamou (Tinamus osgoodi hershkovitzi). The Auk 132:533-539.

O'Brien, T. G., and M. F. Kinnaird (2008). A picture is worth a thousand words: The application of camera trapping to the study of birds. Bird Conservation International 18:S144-S162.
Pardo, L. E., L. Lafleur, R. M. Spinola, J. Saenz, and M. Cove (2017). Camera traps provide valuable data to assess the occurrence of the Great Curassow Crax rubra in northeastern Costa Rica. Neotropical Biodiversity 3:182-188.

Peres, C. A. (2001). Synergistic effects of subsistence hunting and habitat fragmentation on Amazonian forest vertebrates. Conservation Biology 15:1490-1505.

Powell, L. L., P. C. Stouffer, and E. I. Johnson (2013). Recovery of understory bird movement across the interface of primary and secondary Amazon rainforest. The Auk 130:459-468.

Radachowsky, J., V. H. Ramos, R. McNab, E. H. Baur, and N. Kazakov (2012). Forest concessions in the Maya Biosphere Reserve, Guatemala: A decade later. Forest Ecology and Management 268:18-28.

R Core Team (2013). R: A Language and Environment for Statistical Computing. Foundation for Statistical Computing, Vienna, Austria.

Redford, K. H. (1992). The Empty Forest. BioScience 42:412-422.

Richards, S., M. Whittingham, and P. Stephens (2011). Model selection and model averaging in behavioural ecology: The utility of the IT-AIC framework. Behavioral Ecology and Sociobiology 65:77-89.

Sader, S. A., and A. T. Joyce (1988). Deforestation rates and trends in Costa Rica, 1940 to 1983. Biotropica 20:11-19.

Sandor, M. E., and R. L. Chazdon (2014). Remnant trees affect species composition but not structure of tropical secondgrowth forest. PLOS One 9:e83284.

Schelsky, W. M. (2004). Research and conservation of forestdependent tinamou species in Amazonia Peru. Ornitología Neotropical 15:317-321.

Sekercioglu, C. H. (2006). Increasing awareness of avian ecological function. Trends in Ecology \& Evolution 21:464471.

Strahl, S. D., and Grajal, A. (1991). Conservation of large avian frugivores and the management of Neotropical protected areas. Oryx 25:50-55.

Thiollay, J.-M. (2005). Effects of hunting on Guianan forest game birds. Biodiversity and Conservation 14:1121-1135.

Thomson, J. R., A. J. Moilanen, P. A. Vesk, A. F. Bennett, and R. Mac Nally (2009). Where and when to revegetate: A quantative method for scheduling landscape reconstruction. Ecological Applications 19:817-828.

Thornton, D. H., L. C. Branch, and M. E. Sunquist (2012). Response of large galliforms and tinamous (Cracidae, Phasianidae, Tinamidae) to habitat loss and fragmentation in northern Guatemala. Oryx 46:567-576.

Urquiza-Haas, T., C. A. Peres, and P. M. Dolman (2009). Regional scale effects of human density and forest disturbance on large-bodied vertebrates throughout the Yucatán Peninsula, Mexico. Biological Conservation 142:134-148.

Vas, K. (2013). Birding Trails as Sustainable Tourism Development. OIDA International Journal of Sustainable Development 6:23-34.

Vaughan, C. (2012). Creating wildlands in Costa Rica: Historical ecology of the creation of Corcovado National Park. Cuadernos de Investigación UNED 4:55-70.

Weissenhofer, A., W. Huber, N. Zamora, A. Weber, and J. González (2001). A brief outline of the flora and vegetation of the Gulfo Dulce region. In An Introductory Field Guide to the Flowering Plants of the Gulfo Dulce Rainforests, Costa 
Rica: Corcovado National Park and Piedras Blancas National Park (A. Weber, Editor). Stapfia 78.

Wenny, D. G., T. L. Devault, M. D. Johnson, D. Kelly, C. H. Sekercioglu, D. F. Tomback, and C. J. Whelan (2011). The need to quantify ecosystem services provided by birds. The Auk 128:1-14.

Whelan, C. J., D. G. Wenny, and R. J. Marquis (2008). Ecosystem services provided by birds. Annals of the New York Academy of Sciences 1134:25-60.

Whitworth, A., and R. Williams (2017). Camera traps confirm southward range extension and first records of Red-winged Wood Rail (Aramides calopterus) in Madre de Dios, Peru. Cotinga 39:89-91.

Whitworth, A., C. Beirne, J. Rowe, F. Ross, C. Acton, O. Burdekin, and P. Brown (2015). The response of faunal biodiversity to an unmarked road in the western Amazon. Biodiversity and Conservation 24:1657-1670.

Winarni, N., J. P. Carroll, and T. G. O'Brien (2005). The application of camera traps to the study of Galliformes in southern Sumatra, Indonesia. In Galliformes 2004: Proceedings of the 3rd International Galliformes Symposium (R. A. Fuller and S. J. Browne, Editors). World Pheasant Association, Fordingbridge, UK. pp. 109-121.

Wright, S. J. (2003). The myriad consequences of hunting for vertebrates and plants in tropical forests. Perspectives in Plant Ecology, Evolution and Systematics 6:73-86.

Yumoto, T. (1999). Seed dispersal by Salvin's Curassow, Mitu salvini (Cracidae), in a tropical forest of Colombia: Direct measurements of dispersal distance. Biotropica 31:654-660. 